\title{
HENRI PIRENNE (1862-1935) Godfather van de Gentse historische school?
}

\author{
Marc Boone
}

'Une avalanche d'honneurs' of nog 'un ensemble barnumesque' met deze woorden karakteriseerde J. Dhondt in 1966 in wat een van de meest geslaagde analyses van het 'fenomeen Pirenne' blijft, de stortvloed aan eerbewijzen, gelegenheidspublicaties, eredoctoraten, herdenkingszittingen die Henri Pirenne reeds tijdens zijn leven te beurt vielen, en die na zijn overlijden bleven aanhouden. Het overlijden van Pirenne was op zich ook een gelegenheid waarbij de Belgische natie de kans aangreep om haar erkenning te betuigen aan de historicus die met zijn 'Histoire de Belgique' diezelfde natie een historische legimitatie van hoog wetenschappelijk niveau had bezorgd. In tegenstelling tot wat de 'communis opinio' voorhoudt, werd niet in een staatsbegrafenis voorzien. Maar: de officiële aanwezigheid van twee ministers namens de regering (Paul Hymans en Hendrik De Man) en van eerste minister van Zeeland en minister De Schrijver, de nationale persbelangstelling, het sluiten die dag ten teken van rouw van de Koninklijke Bibliotheek, het opschorten van de lessen aan de ULB, de officiële aanwezigheid van politieke, militaire en academische hoogwaardigheidsbekleders uit binnen- en buitenland (met als belangrijkste delegatie: de Franse, vertegenwoordigd door haar ambassadeur, de mediëvisten Marc Bloch en Georges Espinas, en de rector van de Sorbonne), het was duidelijk dat niet enkel van de mens Pirenne, maar ook van een symbool afscheid werd genomen op de door typisch Belgisch druilerig weer gekenmerkte maandag 28 oktober $1935^{1}$. Pirenne is bovendien de enige Belgische historicus wiens beeltenis ooit een postzegel sierde, de emissie dateert van 1962, precies een eeuw na Pirennes geboorte! De reeds vermelde bijdrage van Jan Dhondt over Pirenne is kritisch, maar ook lovend, en zoals wel meer gebeurt met historiografische opstellen, leert het ook veel zoniet meer over haar auteur, Dhondt, dan over het eigenlijke voorwerp van studie, Pirenne. De slotbemerking van Dhondt verdient het toch in dit verband om geciteerd te

1 Een omstandige beschrijving van de eerbewijzen en het verloop van de plechtigheid treft men aan in de klassieke Pirenne biografie: B. LyoN, Henri Pirenne. A biographical and intellectual study, Gent, 1974, p. 391-395. Over dit werk werd in de Handelingen van de Maatschappij een discussie gevoerd, zie: W.P. BLockMANS, Mandarijnenhulde en wetenschapsgeschiedenis, in: Handelingen der Maatschappij voor Geschiedenis en Oudheidkunde te Gent, n.s. 29, 1975, p. 27-37. Een verslag en documenten over de eerbewijzen die bij het overlijden van Pirenne werden geformuleerd treft men aan in Henri Pirenne. Hommages et souvenirs, 2 delen, Brussel, 1938. Een indringende biografische schets werd door F.L. Ganshof over Pirenne geschreven in de Biographie Nationale, XXX, 1958, electronisch beschikbaar via http://digitheque.ulb.ac.be/fr/digitheque-henri-pirenne/biographie/la-vie/index.html. 


\section{MARC BOONE}

worden: « Si, comme je le crois, la tâche ultime de l'historien est de faire penser des générations, si ce n'est pas les pages imprimées qui importent, mais la vie nouvelle qui en jaillit, alors on conviendra que Henri Pirenne, pour avoir fait penser deux générations, est l'égal des plus grands »2.

In wat volgt zal geen volledige schets van het leven en werk van Pirenne gegeven worden. Wel gaat aandacht, naast enkele algemene beschouwingen over de grote thema's die in zijn werk te onderscheiden zijn, naar het omschrijven van Pirenne als een geëngageerde historicus die gedwongen door de actualiteit van zijn tijd (de voor hem zowel in persoonlijk als in wetenschappelijk opzicht uiterst dramatische eerste wereldoorlog), en door zijn maatschappelijke en academische verantwoordelijkheden opvattingen heeft verwoord, waaruit onder meer zijn 'moderniteit' naklinkt en de voorlopersrol gestalte kreeg die hij bekleedde in de context van dé vernieuwende beweging bij uitstek in het bezadigde wereldje van historici in de eerste decennia van de twintigste eeuw, de Annales-school ${ }^{3}$.

\section{Mediëvistiek in Gent voor de benoeming van H. Pirenne}

Op 9 september 1886 - amper drie jaar na het behalen van zijn doctoraat in Luik, waar hij een eerste korte leeropdracht voor paleografie en diplomatiek had gekregen in september 1885 - wordt Henri Pirenne in Gent voor de vakken algemene geschiedenis der middeleeuwen en geschiedenis van België benoemd. Hij zal er 46 jaar blijven onderwijzen tot hij op 20 mei 1930 op eigen verzoek tot het emeritaat wordt toegelaten, met onderbrekingen tijdens de oorlogsperiode van 1916 tot 1918. Voor Pirenne in Gent werd aangesteld, beantwoordde enkel de kort voordien (in 1883) benoemde Paul Fredericq (1850-1920) aan de in die tijd in landen als Duitsland en Frankrijk gestelde eisen inzake wetenschappelijke basis voor het onderwijs (doctoraat op proefschrift, onderwijs dat niet louter via de ex cathedra formule verliep, maar ook op praktische oefeningen stoelde enz...). De vele voorgangers van Pirenne en Fredericq, die in 2005 even kort in het licht werden gesteld naar aanleiding van een door het 'Einhard onderzoeksinstituut voor middeleeuwse studies' aan de UGent georganiseerde tentoonstellng 'Van Romantiek tot Wetenschap: een hobbelig parcours. Een eeuw mediëvisten aan de

2 J. DHONDT, Henri Pirenne: historien des institutions urbaines, in: « Annali della fondazione italiana per la storia amministrativa », III, 1966, (heruitgegeven in Mensen en machten. De belangrijkste studies van Jan Dhondt over de geschiedenis van de 19de en 20ste eeuw, Gent, 1976, p. 119).

3 Dit sluit aan bij de vergelijking tussen twee grote tijdgenoten (en vertegenwoordigers van de historische scholen in België en Nederland): Pirenne en Huizinga, die ik in mijn inaugurale les bij de aanvang van een binnenlandse Francqui-leerstoel aan de ULB op 14 maart 2006 heb uitgesproken: L'automne du moyen âge : Johan Huizinga et Henri Pirenne ou plusieurs vérités pour la même chose. Een publicatie van deze lessenreeks die liep onder de titel "Emergence d'une modernité civique: la société urbaine des anciens Pays-Bas" is in voorbereiding. 


\section{HENRI PIRENNE}

Gentse universiteit (1817-1914)'4 beantwoordden niet aan deze maatstaf. Met uitzondering van rechtshistoricus Leopold-August Warnkoening (in Gent actief in de jaren 1831-36) en historicus en literatuurwetenschapper Constant Serrure (in Gent hoogleraar tussen 1835 en 1871), waren het figuren (zoals de Fransman Henri-Guillaum Moke, hoogleraar geschiedenis 1835-1862) die eerder door de romantiek dan door een positivistisch ingestelde wetenschapsbeoefening werden gekenmerkt. Daar kwam grondig verandering in met het aantreden van historici van de generatie Fredericq en Pirenne. Ook in de andere afdelingen van de Letterenfaculteit, bij de beoefenaars van letterkunde en taalkunde waaide in die jaren een nieuwe geest, met als gevolg dat bij een programma hervorming in 1890 definitief de literaire spielerei werd achterwege gelaten voor een kritisch professionalisme, met praktische oefeningen (cours pratiques) en doctoraat op proefschrift als sleutelelementen 5 .

\section{Methodologische vernieuwing en onderzoeksthema's in het oeuvre van Henri Pirenne}

Pirenne bracht bij zijn aanstelling in Gent heel wat intellectuele bagage mee die hem perfect in deze overgang van literair dilettantisme naar wetenschappelijke geschiedbeoefening doet passen. Om te beginnen was hij in Luik de leerling van Godefroid Kurth (1847-1916) geweest en Kurth was zelf een door de Duitse wetenschap beïnvloed historicus die als eerste in België het seminariesysteem heeft toegepast ${ }^{6}$. Tijdens het jaar tussen zijn promotie en zijn

$4 \quad$ Zie de 'wandelgids' die ter begeleiding van de tentoonstellingsbezoeker (de tentoonstelling liep van de $25^{\mathrm{e}}$ februari tot de $25^{\mathrm{e}}$ maart 2005 in de Centrale Bibliotheek van de UGent) werd opgesteld en die essentieel een korte bio-bibliografische schets van de weerhouden mediëvisten bevat, uitgegeven door de Einhard Stuurgroep o.l.v. Th. de Hemptinne. De hoofdstukken over de Gentse historici mediëvisten voor Pirenne die hier ter sprake komen zijn van de hand van W. Prevenier.

5 Over deze nog niet grondig bestudeerde periode in de historiografie zie W. Prevenier, De mislukte lente van de eruditie in België na 1830, in: J. TollebeeK, G. VerBEECK, T. VERSCHAFFEL (red.) De lectuur van het verleden. Opstellen over de geschiedenis van de geschiedschrijving aangeboden aan Reginald de Schryver, Leuven, 1998 (Symbolae facultatis litterarum Lovaniensis series A, vol. 24), p. 263-272.

6 Ook Fredericq was deels in Luik gevormd en had er in de kringen rond Kurth verkeerd (tussen 1879 en 1883 is ook Fredericq hoogleraar in Luik), zie over Fredericq met verwijzingen naar eerdere literatuur en naar de bronnen: J. TOLLEBEEK, Writing the Inquisition in Europe and America. The correspondence between Henry Charles Lea and Paul Fredericq, Bruxelles, Commission Royale d'histoire, 2004, p. XXVII-XLIII. Over Pirenne als leerling van Kurth in Luik: Léon-E. HALKIN, Henri Pirenne à Liège, in: F. BIERLAIRE, J.-L. KUPPER (éd.), Henri Pirenne de la cité de Liège à la ville de Gand. Actes du colloque organisé à Liège le 13 décembre 1985, Cahiers de Clio, 86, 1986, p. 13-22. In de ideologische erg geladen sfeer van 1879 was de keuze gemaakt door de liberaal Pirenne om college te volgen bij de als katholiek bekend staande Kurth allesbehalve evident, in de woorden van Pirenne zelf 'Ce fut un scandale que l'arrivée d'un gibelin parmi tous ces guelfes'! 


\section{MARC BOONE}

eerste Luikse aanstelling zal de jonge Pirenne een volledig jaar in Duitsland studeren (het academiejaar 1884-85). Concreet studeert hij er in Berlijn bij Harry Bresslau paleografie, bij Gustav Schmoller economische geschiedenis en in Leipzig bij Wilhelm Arndt instellingengeschiedenis, diplomatiek bij Friedberg 7 . Deze oriëntering op Duitsland, ook al zal hij ze in de dramatische ontwikkeling van de eerste Wereldoorlog in vraag stellen en naderhand zeer actief afzweren, heeft Pirenne blijvend als historicus getekend, vooral de band die hij tot aan diens overlijden met een van de Duitse tophistorici, Karl Lamprecht heeft gecultiveerd. Daarnaast studeerde Pirenne in deze cruciale jaren tussen het doctoraat en de aanvaarding van een professoraat ook in Parijs, aan de 'Ecole des Chartes' en de 'Ecole pratique des Hautes Etudes', dit laatste bij Giry: ook hier weer met een opvallende klemtoon op 'praktisch' onderwijs, volgens het Duitse seminariemodel.

De grote inspirator blijft evenwel Karl Lamprecht (1856-1915), in die jaren de centrale figuur in de ontwikkeling van de Duitse geschiedschrijving. Reeds tijdens zijn leven was Lamprecht een omstreden figuur, in die mate dat hij in het centrum van de zogenaamde 'Methodenstreit' (die daarom soms ook de Lamprechtstreit wordt genoemd) is terecht gekomen. Het ging daarbij om een nogal heftig gevoerd wetenschappelijk dispuut tussen neorankianen (en eigenlijk neokantianen) die een ideografische opvatting over de geschiedenis voorstonden en historici die in het kielzog van Lamprecht een eerder nomothetische opvatting over de geschiedenis huldigen ${ }^{8}$. De herinnering aan Lamprecht is dan ook levendig gebleven ${ }^{9}$. Recent, in 1991, opmerkelijk genoeg maar niet toevallig zeer kort na de 'Wende', is aan de universiteit Leipzig, de instelling waarmee hij bij zijn leven geïdentificeerd is geworden (hij bekleedde er sinds 1891 een leerstoel), een Karl-Lamprecht-Gesellschaft opgericht - dat interdisciplinariteit en comparatieve geschiedenis hoog in het vaandel voert - en

7 Over deze Duitse mediëvisten zie de notities in R. vom BRUCH, R. A. Müller (ed.), Historikerlexikon. Von der Antike bis zur Gegenwart, München, 2002 ( $2^{\text {de }}$ editie), passim.

8 Betreffende Lamprecht, en de 'Methodenstreit' uitgelokt door de twaalf delen van zijn 'Deutsche Geschichte' vanaf 1891 : G. OESTREICH, Die Fachhistorie und die Anfänge der sozialgeschichtliche Forschung in Deutschland, in : "Historische Zeitschrift », 208, 1969, p. 320-363; R. VOM BRUCH, Wissenschaft, Politik und öffentliche Meinung. Gelehrtenpolitik im wilhelmischen Deutschland (1890-1914), Husum, 1980.

9 Ook in Nederland, op een historicus als Blok, zelf leermeester van Huizinga, had Lamprecht een zeer grote invloed: J. TOLLEBEEK, Historiografie en politiek omstreeks de eeuwwende: Bloks sociale geschiedenis, in: "Tijdschrift voor sociale geschiedenis", 13/2, 1987, pp. 132-137; betreffende zijn invloed en relatie tot Pirenne: B. LyON, The letters of Henri Pirenne to Karl Lamprecht, in: Bulletin de la Commission Royale d'Histoire, 132, 1966, p. 161-231 aan te vullen met H. VAN WERVEKE, Karl Lamprecht et Henri Pirenne, in: Handelingen van de Koninklijke Commissie voor Geschiedenis, 138, 1972, p. 39-60 


\section{HENRI PIRENNE}

dat aansluit bij het "The European Network in Universal and Global History"10.

Van Lamprecht neemt Pirenne essentieel het werken met aan de collectieve psychologie en aan de economie ontleende begrippen over. Lamprecht die een theorie van Kulturstufen (een reeks van culturele ontwikkelingsfasen die elke nationale staat doorliep) ontwikkelde, demonstreerde deze opvattingen in zijn visie op de Duitse geschiedenis. Pirenne zal dit bij de aanvang ook op zijn 'Histoire de Belgique' toepassen. Het eerste deel van zijn bekendste werk de 'Histoire de Belgique' verscheen ten andere in 1899 eerst in het Duits (pas in 1900 volgde de Franse editie), als het ware op bestelling van Lamprecht die het in een door hem geleide reeks wou opnemen. Gaandeweg, en ook hier zal Wereldoorlog I als een cruciaal breukmoment aan te merken zijn, zal Pirenne van de geest en invulling van deze begrippen bij Lamprecht afstand nemen. De zorgvuldige taalkundige analyse die mevrouw Geneviève Warland er recent van bezorgde illustreert deze opmerkelijke evolutie, ze levert aldus een genuanceerder beeld op van het historisch denken van Pirenne, dan wat velen er achteraf van gemaakt hebben ${ }^{11}$.

Globaal genomen kunnen in het oeuvre van Pirenne drie thema's onderscheiden worden die in verschillende varianten terugkeren en waarrond zich een onderzoekstraditie heeft gevormd, ook al zijn de meeste van zijn opvattingen bijgesteld, verworpen en omgebogen. Zoals het bij de aanvang aangehaalde citaat van Dhondt nog bevestigt: Pirenne heeft generaties historici na hem aan het denken gezet en een aantal ankerpunten uitgezet waarrond veel hedendaags onderzoek nog steeds draait. Ze komen ten andere ook op merkwaardige wijze terug voor in een van zijn grote syntheses, tot stand gekomen tijdens de jaren van gevangenschap in Duitsland, de Histoire de l'Europe. Des invasions au XVIe siècle (postuum gepubliceerd in 1936).

$\mathrm{Er}$ is vooreerst het thema van de nationale geschiedenis, met het grote magnum opus de 'Histoire de Belgique' als uithangbord. In de opvatting van

10 Zie de websites: http://www.lamprecht-gesellschaft.de/ en http://www.eniugh.org/ (geconsulteerd op 8-11-2006)

11 G. WARLAND, Les métaphores de la nation chez Henri Pirenne et Karl Lamprecht. Entre romantisme et humanisme, in : H. RoLAND, S. ScHMITZ (ed), Pour une iconographie des identités culturelles et nationales. La construction des images collectives à travers le texte et l'image, Frankfurt-Berlin, Peter Lang, 2004, p. 179207 ; zie ook van haar (ter perse) Rezeption und Wahrnehmung der deutschen Geschichtswissenschaft bei belgischen 'Epigonen' : Paul Fredericq (1850-1920), Godefroid Kurth (1847-1916) und Henri Pirenne (1862-1935), in : M. BEYEN, G. DRAYE, H. Roland, Deutschlandbilder in Belgien, 1830-1945, Münster, 2006 passim. De analyse van Warland laat toe om de opvattingen van bijvoorbeeld J. Dhondt dienaangaande op gepaste wijze te nuanceren. 


\section{MARC BOONE}

Pirenne zijn het voornamelijk sociale en economische situaties (concreet: de verstedelijkte samenleving) die de basis voor een politiek eenwordingsproces hebben gecreëerd, de Bourgondische periode bood aldus de eerste manifestatie van dit eenheidsstreven. Men heeft voor deze opvattingen Pirenne, niet geheel ten onrechte een teleologische opvatting verweten, maar voornamelijk heeft recent onderzoek afstand genomen van zijn voorstelling dat vanaf de Bourgondische tijd de centrale overheid (de hertogen en hun administratie) de drijvende krachten leverde achter het eenwordingsproces; ook aan de door hem negatief ingeschatte stedelijke tegenkrachten, het geheel van corporatief georganiseerde economische, politieke en culturele instellingen, dat in de steden actief was, wordt nu recht gedaan.

Het tweede centrale thema is dat van de stadsgeschiedenis, waarbij Pirenne het primaat van de handelseconomie als drijvende kracht voorop plaatst. Het is daar dat hij verklaringen zoekt, zowel voor het ontstaan van steden als voor de latere ontwikkelingen van het handelskapitalisme, opnieuw op basis van vele voorbeelden die aan de geschiedenis der Nederlanden (vaak dan nog gereduceerd tot de Maasvallei en het oude graafschap Vlaanderen) zijn ontleend. Dit onderzoeksthema heeft op zijn beurt veel vernieuwend onderzoek gestimuleerd - men denke aan de worsteling van wijlen Adriaan Verhulst met het onderwerp van het ontstaan van de steden - en doet dat nog steeds ${ }^{12}$.

Derde thema is dat wat men als de 'Pirenne-thesis' is gaan beschouwen, de stelling dat de breuk tussen oudheid en middeleeuwen er is gekomen ten gevolge van het succes van de Islam, synthetisch naar voren gebracht in andermaal een postuum boek, 'Mahomet et Charlemagne' uit 1937 (maar aangekondigd in publicaties over stadsgeschiedenis uit de jaren 1893 en 95) en in zijn rede op het internationaal historisch congres in Oslo in 1928 (waar al meteen de controverse ontstaat die na het verschijnen van het boek een hoogtepunt zal kennen) ${ }^{13}$.

12 Een laatste synthese: A. VERHULST, The rise of cities in North-West Europe, Cambridge, 1999, stedelijke geschiedschrijving waarin vele van de door Pirenne gelanceerde stellingen kritisch tegen het licht worden gehouden vindt plaats in de verschillende onderzoeksprojecten (IUAP's van de POD wetenschapsbeleid van de Belgische federale diensten) onder leiding van ondergetekende, een overzicht van de thema's uit de fases V (2002-2006) en VI (2007-2011) treft men aan op http://www.ulb.ac.be/philo/urbs/. Zie ook de bijdragen van R. VAN UYTVEN en van W. PREVENIER in: La fortune historiographique des thèses d'Henri Pirenne. Actes du colloque organisé à l'occasion du cinquantenaire de la mort de l'historien belge par l'Institut des Hautes Etudes de Belgique par G. Despy et A. Verhulst, Bruxelles 1011 mai 1985, Brussel, 1986 (Archives et bibliotheqques de Belgique, numéro spécial 28).

13 Ook hier kan men de evolutie van de opvattingen terzake best meten door kennis te nemen van de recente synthese over de Karolingische economie : A. VERHULST, The Carolingian economy, Cambridge, 2002 en een recente stand van zaken: J.-P. DeVROEY,Puissants et misérables. Système social et monde paysan dans l'Europe des Francs (VIe-IXe siècles), Brussel, 2006, passim. 


\section{HENRI PIRENNE}

Met deze thema's heeft Pirenne de geschiedbeoefening, die in zijn tijd nog in heel sterke mate samenviel met de mediëvistiek in België en in Gent in het bijzonder op de kaart geplaatst, als er al van schoolvorming sprake kan zijn dan in die mate dat verschillende van die thema's in de op hem volgende generaties zijn doorgegeven, bijgesteld, gecorrigeerd maar steeds een bron van inspiratie zijn gebleven.

Bovenop de inhoudelijke thema's is er uiteraard de methodologische vernieuwing: een solide basis verworven vanuit het beheersen van hulpwetenschappen en vaktechniek, met daarnaast een internationaal gerichte en comparatief opgevatte vraagstelling die bewust (in de geest van Lamprecht) inspiratie zoekt bij andere sociale wetenschappen.

\section{Invloed en internationale uitstraling}

De onderzoeksresultaten van Pirenne zijn reeds tijdens het leven van de auteur voorwerp van grote internationale belangstelling geweest, de reeds aangehaalde omschrijvingen van Dhondt zijn dan ook meer dan terecht. In een recent opstel over het grote internationale historische congres van 1955 in Rome, twintig jaar na de dood van Pirenne en het tweede naoorlogse congres (in 1950 was in Parijs de draad van de internationale bijeenkomsten weer opgenomen) toont Jo Tollebeek aan hoe de Belgische delegatie nog steeds door de geest van Pirenne werd beïnvloed ${ }^{14}$. De forse Belgische delegatie werd overigens door een aantal directe Gentse leerlingen van Pirenne, François Louis Ganshof, Fernand Vercauteren, en Charles Verlinden gedomineerd, andere Belgische zwaargewichten waren op cruciale momenten van hun academische carrière door tussenkomsten van Pirenne geholpen geweest (Paul Bonenfant, Paul Harsin). De geest van Pirenne die zelf een van de voorafgaande congressen van de CISH (comité international des sciences historiques) had georganiseerd en voorgezeten - het congres van Brussel in 1923 waar hij het voorzitterschap van het comité dat hem werd aangeboden geweigerd had - overvleugelde zeker wat het opgemerkte optreden van de Belgische delegatie aanging, nog steeds het gebeuren. Ook inzake de overdonderende belangstelling voor één periode (de middeleeuwse geschiedenis) en wat de klemtoon op sociaal-economische geschiedenis betrof. De geest van de zogenaamde tweede Annales school (met Fernand Braudel als sleutelfiguur) en haar agenda domineerde anno 1955 de historische wetenschap, de meeste Belgische deelnemers sloten daar inzake thematiek en chronologische belangstelling erg vlot bij aan. De opvallende aanwezigheid van de leerlingen van Pirenne in Rome in 1955 werd vertaald als

14 J. TOLLEBEEK, Rome in 1955. Een momentopname van de Belgische en Nederlandse geschiedschrijving, ter perse in Belgisch Tijdschrift voor Filologie en Geschiedenis, 85, 2007. 


\section{MARC BOONE}

een manifestatie van niet zozeer een 'Gentse' dan wel van een 'Belgische historische school', zoals Vercauteren bij een terugblik enkele jaren nadien zou verwoorden ${ }^{15}$. In zijn studie over nationale geschiedschrijving in België en Nederland in de jaren kort voor tot kort na Wereldoorlog II (1938-1947) stelt Marnix Beyen ook onomwonden dat indien Belgische historici zich als een 'school' presenteerden, dit onder verwijzing naar Pirenne gebeurde, ze beschouwden zich als de intellectuele kinderen van Pirenne. Hij waagt zich ook aan een soort robotfoto:

'Eerder dan met Pirenne te worstelen, leken de Belgische historici zonder meer in het voetspoor te willen treden van hun grote voorbeeld. Het Belgisch historisch bedrijf werd in de late jaren dertig dan ook gedomineerd door een type historicus dat grote verwantschappen vertoonde met Pirenne. Zij waren veelal mediëvisten van oorsprong en bezaten een grote methodologische onderlegdheid (vaak waren zij ook bronnenuitgevers en verscheidene onder hen hadden enige tijd in het archiefwezen gewerkt). Bovendien waren de meesten onder hen overtuigd van de invloed van economische factoren op de (politieke) geschiedenis. Na de benoeming van Jan Van Houtte gold dat zelfs voor de katholieke Leuvense universiteit. Net als Pirenne waren zijn epigonen zowel op de Franse als op de Duitse historische wereld gericht. In tegenstelling tot hun Nederlandse collega's waren zij over het algemeen vertrouwd met de aspiraties en verwezenlijkingen van de Annales-school. De evidentie van dat pirennistische model lijkt mede aan de oorsprong te hebben gelegen van het theoretische deficiet van de Belgische historische wereld. Ook het feit dat de geschiedenis van de geschiedschrijving als discipline in België nauwelijks was ontwikkeld, lijkt zijn oorsprong althans gedeeltelijk in die vanzelfsprekendheid te vinden' 16.

Er was met andere woorden na Pirenne geen behoefte aan een intern debat over waarheen met de geschiedwetenschap, hard werken en voortdoen in de door de leermeester uitgezette richting leek het parool te zijn.

Maar ook bij de Annales was Pirenne, van bij de beginjaren van het tijdschrift dat in 1929 van start ging, heel nauw betrokken geweest. Aan de Amerikaanse biograaf van H. Pirenne, Bryce Lyon, danken we een editie van de correspondentie tussen Pirenne en de twee stichters van de Annales, Marc Bloch en Lucien Febvre ${ }^{17}$. Beide Franse historici erkenden in Pirenne, steevast als

15 F. Vercauteren, Cent ans d'histoire nationale en Belgique, Brussel, 1959, p. 9-10.

16 M. BEYEN, Oorlog en verleden. Nationale geschiedenis in België en Nederland, 1938-1947, Amsterdam, 2002, p. 388-389.

17 B. EN M. LYON, The birth of Annales history : the letters of Lucien Febvre and Marc Bloch to Henri Pirenne (1921-1395), Brussel, 1991 (Koninklijke Commissie voor Geschiedenis, in- $8^{\circ}$ ), passim. 


\section{HENRI PIRENNE}

'cher maître et ami' bij Febvre,of als 'monsieur et cher maître' (bij Bloch) omschreven, een geestelijk vader, en hebben dan ook gepoogd om hem er reeds in 1921 van te overtuigen als eerste directeur van hun nieuwe, op te richten tijdschrift te fungeren. Dit laatste heeft Pirenne weliswaar geweigerd, maar van bij de aanvang hebben zowel hij als verschillende van zijn directe leerlingen regelmatig in het tijdschrift gepubliceerd en het steeds een erg warm hart toegedragen. Daarvoor zijn een aantal inhoudelijke overwegingen aan te geven, de vernieuwing van de Annales sloot inhoudelijk in vele opzichten aan bij de richting waarin reeds Lamprecht de geschiedenis had willen stuwen. Maar van bij de aanvang is het duidelijk dat in de nadagen van Wereldoorlog I ook andere motieven meespelen: met de Annales wilden Bloch en Febvre toen nog in Straatsburg actief een alternatief bieden voor het Duitse 'Vierteljahrschrift für Sozial und Wirtschaftsgeschichte' dat reeds in 1919 opnieuw was van start gegaan en dat een monopolie positie op het terrein van de sociaal-economische geschiedenis dreigde te gaan innemen. Vergeten we niet dat ook de Annales, in hun eerste fase door de ondertitel 'Annales d'histoire économique et sociale' gekenmerkt, zich uitgerekend ook op dit terrein wilden manifesteren. In deze anti-Duitse demarche, Bloch zelf was tijdens de oorlog frontsoldaat geweest, was Pirenne een voor de hand liggend bondgenoot. Heel recent verscheen een verzameling van gedeeltelijk reeds eerder uitgegeven maar ook van onuitgegeven geschriften, wetenschappelijke publicaties, fragmenten uit brieven, egodocumenten allerhande, van de hand van Marc Bloch waarin de verwijzingen naar Pirenne legio zijn, vaak gekruid met een sterk persoonlijke noot en dit in de pen van een man die niet met zijn ziel te koop liep, maar waarvan de intellectuele eerlijkheid en rigueur boven alle twijfel verheven staan. In een brief aan zielsverwant Fevre uit 1935 schrijft Bloch bijvoorbeeld, na het overlijden van Pirenne vernomen te hebben 'Entendu pour les hommages funèbres à notre pauvre Pirenne, dont la disparition va creuser pour nous deux un grand vide. Même quand on ne le voit pas, pendant longtemps, il faisait bon savoir vivre avec ce Vivant' 18.

Aan deze op het eerste gezicht wetenschappelijke opgang en carrière was ook een schaduwzijde verbonden: de Eerste Wereldoorlog was namelijk voor Pirenne een zware beproeving geworden, zowel op persoonlijk als op wetenschappelijk vlak. Al tijdens de eerste maanden van de oorlog sneuvelde zijn zoon Pierre aan het Ijzerfront en vele jarenlange vriendschappen met Duitse collega's bleken niet bestand tegen de opstoot van nationalistische waanzin die Europa in die jaren in de ban hield. Vooral de breuk met Karl Lamprecht moet wonden gelaten hebben: Lamprecht was een der 93 ondertekenaars van de 'Aufruf an die Kulturwelt' waarmee vooraanstaande Duitse intellectuelen de Duitse agressie verantwoorden en vergoelijkten en stelling namen tegen de

18 A. BeCKer, E. Bloch (éd.), Marc Bloch, l'histoire, la guerre, la résistance, Parijs, 2006, p. 41. 


\section{MARC BOONE}

beschuldiging van gruweldaden begaan tijdens de opmars door België, met de verwoesting van Leuven en de executies in Dinant als internationaal meest bekend wapenfeit ${ }^{19}$. Naast Lamprecht hadden ook andere invloedrijke en belangrijke historici als Schmoller en Sombart de oproep mee ondertekend. In een analyse van onderlinge correspondentie en van de sinds 1970 publiek toegankelijke dagboeken van Fredericq heeft Hans van Werveke in 1972 aangetoond hoe de missie van Lamprecht namens de Duitse keizer om Vlaamse intellectuelen (en in de eerste plaats de groep rond Pirenne) tot een collaboratie met de Duitse bezetter te bewegen, tot een fatale breuk heeft gevoerd ${ }^{20}$. Kort na een confrontatie in het Brusselse stadhuis met Pirenne's leerling Guillaume Des Marez (archivaris van Brussel en hoogleraar aan de ULB) is Lamprecht naar Duitsland teruggekeerd en overleden ${ }^{21}$.

\section{Pirenne als symbool voor 'poor little Belgium'}

De betekenis van Pirenne als Belgisch symbool tijdens de eerste Wereldoorlog gaat uiteraard veel verder dan het directe, persoonlijke verlies en de breuk met Lamprecht.

Wanneer op 16 maart 1916 Duitse soldaten Pirenne en Fredericq uit Gent wegvoeren en naar Duitsland deporteren ${ }^{22}$ worden beiden symbool van weerstand (tegen de door de bezetter opgelegde vernederlandsing en tegen de manier waarop het oorlogvoerende Duitsland zich in België in het algemeen gedraagt)

19 Over deze Duitse wandaden is tot in de jaren vijftig van de twintigste eeuw geredetwist, een huidige stand van zaken, die in vele aspecten een verpletterende Duitse verantwoordelijkheid blootlegt bij J. HORNE, A. KRAMER, 1914. Les atrocités allemandes, Paris, 2005, p. 313-320 over de 'Aufruf' en de discussies tussen geleerden aan beide zijden van het front (oorspronkelijke Engelse editie van het werk van Horne en Kramer dateert uit 2001).

20 H. VAN WERVEKE, Karl Lamprecht et Henri Pirenne, in: Handelingen van de Koninklijke Commissie voor Geschiedenis, CXXXVIII, 1972, p. 39-60.

21 Over Pirenne en Des Marez: B. LyoN, Guillaume Des Marez et Henri Pirenne : a remarkable rapport, in : Belgisch Tijdschrift voorFilologie en Geschiedenis, 77,1999 , p. 1051-1078.

22 Pirenne zal eerst in een gevangenkamp voor officieren in Crefeld, daarna van 12 mei 16 tot 28 augustus 16 in het kamp van Holzminden en nadien onder druk van de internationale wetenschappelijke gemeenschap en van politieke autoriteiten zoals de amerikaanse president Wilson en de paus, onder toezicht geplaatst in de universiteitstad Jena, van waaruit beide Gentse hoogleraren beschuldigd van antiDuitse agitatie, opnieuw gedeporteerd worden in ballingschap in een dorpje in Thüringen in Creuzburg, in de buurt van Eisenach. Een overzicht (waarin ook kritisch wordt ingegaan op de 'mythe' dat Pirenne geen toegang tot boeken of tot een bibliotheek zou hebben gehad): G. WARLAND, L'Histoire de l'Europe de Henri Pirenne: genèse de l'oeuvre et représentation en miroir de l'Allemagne et de la Belgique, in: Textyles. Revue des lettres belges de langue française, $\mathrm{n}^{\circ} 24,2004$, p. 38-81. 


\section{HENRI PIRENNE}

samen met kardinaal Mercier, burgemeester Adolphe Max van Brussel, koning Albert I. Tijdens deze Duitse gevangenschap is Pirenne ook niet als wetenschapper blijven stilzitten: hij heeft zijn 'Histoire de l'Europe' geconcipieerd, zijn stelling die postuum in Mahomet et Charlemagne zal worden geponeerd komt er tot rijpheid, en hij reflecteert veel meer dan men doorgaans aangenomen heeft, over theoretische en andere aspecten van het historisch bedrijf ${ }^{23}$. In een recent, hoogst persoonlijk en van een diep inlevingsvermogen getuigend boek over Pirenne heeft de Italiaanse mediëvist Cinzio Violante (die tijdens Wereldoorlog II een vergelijkbaar lot als dat van Pirenne zal kennen) deze periode geanalyseerd 24 . De titel van Violante's boek 'la fine della grande illusione' zegt veel over de tijdsgeest van de jaren na Wereldoorlog I maar getuigt ook van de moeizame zoektocht, in de context van de oprichting van de Annales naar een nieuwe zingeving voor het historische bedrijf. Pirenne heeft daarvan in zijn vele geschriften die hij tijdens zijn gevangenschap bijhield en waarvan er verschillende zijn uitgegeven getuigenissen nagelaten ${ }^{25}$.

De publieke rol die hem evenwel als symbool van 'poor little Belgium' werd opgedrongen heeft veel energie opgeslorpt, de tijd van gevangenschap door hemzelf gekwalificeerd als ' $n$ 'ayant aucun devoir à accomplir, libre de toute besogne, débarrassé de toutes obligations mondaines et sociales, dans mon isolement je goûtais le charme de la méditation, l'élaboration lente et progressive des idées que l'on porte en soi...'26 mocht dan wel ruimte gelaten hebben voor wetenschappelijke arbeid en voor het nodige denkwerk, na de wapenstilstand van 1918 werd op Pirenne en zijn op zich grote werkkracht van velerlei zijden beslag gelegd. In juni 1919 wordt hij eredoctor van de universiteit van Oxford (als enige wetenschapper naast een reeks maarschalken Joffre, Pershing, Haig, admiraals en politici zoals Herbert Hoover) op 11 november 1919 eredoctor in Straatsburg

23 Zeker op dit terrein moet het opstel van Dhondt bijgesteld worden, zie de aangehaalde bijdragen van $\mathrm{G}$. Warland.

24 C. VIOLANTE, La fine della 'grande illusione'. Uno storico europeo tra guerra e dopoguerra, Henri Pirenne (1914-1923). Per una rilettura della 'Histoire de l'Europe', Bologne, 1997 (Annali dell'Istituto storico italo-germanico. Monografia 31 ) ; zie de notie over dit boek bij P. TouBERT, Henri Pirenne et l'Allemagne (19141923), in : * Le Moyen Age », CVII, 2001, p. 317-320. Sinds kort bestaat het boek ook in het Duits met een belangrijke inleiding over Violante door Giorgio Cracco : C. Violante, Das Ende der 'grossen Illusion'. Ein europäischer Historiker im Spannungsfeld von Krieg und Nachkriegszeit, Henri Pirenne (1914-1923) - Zu einer Neulesung der 'Geschichte Europas', Berlin, 2004, Duncker\&Humblot, (Schriften des Italienisch-Deutschen Historischen Instituts in Trient, Band 18).

25 B. AND M. LyON (ed.), The Journal de guerre of Henri Pirenne, Amsterdam-New York, 1976 en : B. LyON, M. LyoN, J.-H. PIRENNE (+), « Réflexions d'un solitaire » by Henri Pirenne, in : Bulletin de la Commission Royale d'Histoire, CLX, 1994.

26 Aangehaald bij G. WARLAND, L'histoire de l'Europe de Henri Pirenne, p. 40 . 


\section{MARC BOONE}

(zijn eerdere Duitse eredoctoraten in Leipzig en Tübingen had hij teruggestuurd als protest) een plaats en datum die meer dan symbolisch zijn, maar waar hij opnieuw Bloch en Febvre ontmoet ${ }^{27}$. Het is tekenend dat de twee laatste grote publicaties, de Histoire de l'Europe en Mahomet et Charlemagne eigenlijk onafgewerkt zijn gebleven en uiteindelijk postuum uitgegeven werden.

Aan de eigen universiteit werd Paul Fredericq bij de bevrijding rector (op 10 januari 1919) maar al na enkele maanden, meer bepaald op 18 april 1919 nam hij ontslag uit deze functie, ontgoocheld door de felle anti-Vlaamse reacties in deze periode van oplaaiend patriottisme en omwille van gezondheidsproblemen (op 23 maart 1920 werd hij door een beroerte geveld). Pirenne volgde hem op in de jaren 1919-1921. In deze functie hield hij verschillende rectorale redes die allemaal de relatie België-Duitsland als onderwerp had$\mathrm{den}^{28}$. De bekendste daarvan is ongetwijfeld ' $\mathrm{Ce}$ que nous devons désapprendre de l'Allemagne' uitgesproken op 18 oktober 1921. Het verdient aanbeveling deze korte tekst opnieuw door te nemen, want het is een geloofsbelijdenis van een door de omstandigheden getekend man, die een aantal schepen achter zich verbrandt. Over Lamprecht lezen we bijvoorbeeld in een beschouwing over de nefaste invloed van het nationalisme op de geschiedschrijving:

'Il semble presque, à lire cette littérature que ni la Prusse, ni l'Allemagne ne puissent mal faire. Il y a là une sorte de convention tacitement admise, et qui se généralise à mesure que la puissance allemande se manifeste plus lourdement dans le monde. Prenez la dernière histoire de l'Allemagne qui ait été écrite avant la guerre, la Deutsche Geschichte de Karl Lamprecht, débarrassez la des théories fumeuses dont elle s'entoure, et dites s'il a jamais existé un ouvrage où le chauvinisme se révèle avec autant d'aveugle volupté'29.

En Pirenne somt vervolgens in een reeks mooie vergelijkingen de punten op waarin Duitsland historisch achter de ontwikkelingen in de rest van WestEuropa aanhinkt, een thema dat nadien en ook nu door Duitse historici wordt overgenomen: Duitsland als 'Verspätete Nation'. Waar hij zich zo virulent tegen afzet is een opvatting die niet louter Duits is tenandere 'nous sommes si j'ose dire, mal dégorgés, et le langage de mons. Maurice Barrès ne laisse pas que de me rappeler parfois celui de Karl Lamprecht', de grootste bedreiging is immers met name 'cette funeste théorie des races, la plus fausse et la plus décevante qui ait jamais été, car elle permet de tout expliquer sans chercher les raisons de rien' 30 . In tegenstelling daarmee pleit hij voor een univer-

27 B. Lyon, Henri Pirenne. A biographical and intellectual study, p. 282.

28 La nation belge et l'Allemagne. Quelques réflexions historiques (1919), L'Allemagne moderne et l'Empire romain du Moyen Age (1920).

29 H. PIRENNE, Ce que nous devons désapprendre de l'Allemagne. Ouverture solennelle des cours et remise du rectorat, Gent, 1922, p. 15.

30 Ibidem, p. 21. 


\section{HENRI PIRENNE}

sele opvatting, ook en in de eerste plaats, als het over de geschiedenis gaat. Niet verwonderlijk dan ook dat hij voortaan voor een comparatieve geschiedenis pleit, ondermeer in 1923 tijdens het andere grote internationale congres dat hij zelf en zijn leerlingen in Brussel organiseren en waarvan hij officiële vertegenwoordigers van de Duitse wetenschap zal uitsluiten van deelname. Deze roep om comparatieve geschiedschrijving als opstap naar een universele geschiedenis zal door Marc Bloch op de grote internationale conferentie van Oslo in 1928 overgenomen worden ${ }^{31}$.

\section{Henri Pirenne, kind van zijn tijd: de grote ontgoochelde of een strijdbaar intellectueel ondanks alles?}

Een en ander verklaart ook de moeizame relatie van Pirenne met de Vlaamse beweging en zijn onvermogen om ooit met de vernederlandsing van de Gentse universiteit in te stemmen, de herinnering aan de opgelegde vernederlandsing onder de Duitse bezetter en zijn gevangenschap in Duitsland als resultaat van het protest daartegen, was te sterk om veel begrip hiervoor te kunnen opbrengen. De ongenuanceerde opvatting dat Pirenne een Vlamingen-hater zou zijn geweest verdient dienaangaande dan ook op veel scepsis onthaald te worden ${ }^{32}$. Enig herstel van de ook al zeer beproefde relatie met de Duitse wetenschap is er amper gekomen. Wanneer Pirenne in 1935 overlijdt schrijft de Duitse mediëvist Franz Petri (1903-1993) in een in memoriam in het Vierteljahrschrift: 'Es offenbarte sich damals, wie wenig Pirenne trotz seinen vielfältigen wissenschaftlichen und persönlichen Beziehungen, das innerste Wesen des Deutschen und einer um Volksverbundenheit ringenden deutschen Wissenschaft begriffen hat ${ }^{33}$. Een handige poging om het probleem bij

31 Zie hierover A. VeRHuLST, Marc Bloch and Henri Pirenne on comparative history. A biographical note, in: Belgisch Tijdschrift voor Filologie en Geschiedenis, 79,2001 , p. 507-510.

32 Zoals ook overtuigend betoogd bij W. PREVENIER, Pirenne à Gand, in: F. BIERLAIRE, J.-L. KuPPER (éd.), Henri Pirenne de la cité de Liège à la ville de Gand. Actes du colloque organisé à Liège le 13 décembre 1985, Cahiers de Clio, 86, 1986, p. 37-40.

33 Aangehaald bij G. WARLAND, Rezeption und Wahrnehmung, p. 40, Petri zou in 1937 een Habilitation verdedigen over 'Germanische Volkserbe in Wallonien und Nordfrankreich. Die Fränkische Landnahme in Frankreich und in den Niederlanden und die Bildung der westlichen Sprachgrenze', waarmee hij zou uitgroeien tot vertegenwoordiger van de zogenoemde Westforschung, tijdens de bezetting in Wereldoorlog II zou Petri een belangrijke rol in de organisatie van collaboratie bij Vlaamse intellectuelen spelen. Zie over de rol van Petri : M. BEYEN, Oorlog en verleden, p. 80-81, 86-95, 117-118 en passim, over de figuur Petri, ten andere een der eerste Duitse vakhistorici die een genuanceerde visie ontwikkelde op de slachtpartijen op Belgisch grondgebied door Duitse troepen in 1914 en zijn optreden in de context van de Militärverwaltung tijdens Wereldoorlog II: W. DoLDERER, Petri, Franz, in : Nieuwe encyclopedie van de Vlaamse Beweging, Tielt, 1998, p. 2467-2468. 


\section{MARC BOONE}

Pirenne te situeren, en de problematische evolutie van de geschiedwetenschap in Duitsland meteen te minimaliseren. Enige toenadering met Duitsland is te merken in de briefwisseling die Pirenne aan het einde van zijn leven voerde met de jonge aankomende (en wat gemarginaliseerde) Duitse mediëvist Heinrich Sproemberg 34 .

In dit alles is het ook relatief gemakkelijk om een grote dosis van zelfkritiek op het gezapige universitaire leven op te vangen, academici hebben zich in slaap laten wiegen en niet tijdig en zeker niet adequaat gereageerd op de eerste symptomen van een uit de hand gelopen pangermaans nationalisme. Ik citeer nogmaals Pirenne ditmaal uit een bij de koninklijke academie uitgegeven opstel uit 1919 onder de titel 'le pangermanisme et la Belgique':

'Et le plus terrible, ce n'est pas que des publicistes fanatiques aient répandu ce poison à travers la masse, c'est que les philosophes, les historiens, les économistes, les philologues et les sociologues n'aient pas résisté à la contagion, et qu'elle ait infecté ces universités allemandes que l'étranger cependant continuait à admirer béatement comme de sereines écoles de sciences et de critique (...) L'apologie de la Prusse, l'apologie du nationalisme allemand, du génie allemand, de l'art allemand, de la politique allemande, des ambitions allemandes, voilà ce qui s'y déversait à jet continu de la chaire des maîtres dans les crânes dolichocéphales des auditeurs et y fomentait des passions d'autant plus redoutables qu'elles s'imaginaient fondées sur la science. Des générations d'étudiants se formaient là, pour qui rien au monde n'existait plus que l'Allemagne, pleins d'incommensurables mépris pour le reste de l'univers, le considérant comme un champ ouvert à la conquête germanique et attendant avec impatience le moment de la lui imposer'35.

Aan het einde van zijn leven, Pirenne woont dan al in Brussel en doceert er aan de ULB, klinkt deze hartstochtelijke en geëngageerde stem nog eenmaal fors door wanneer hij schrijft aan een tijdgenoot en sinds decennia epistolair vriend Johan Huizinga. Beide historici hadden een groot wederzijds respect voor elkaar en voor hun respectievelijk werk, maar bleven ook gescheiden door een zeer groot verschil in temperament en wetenschappelijke methode.

34 H. SPROEMBERG, Mittelalter und demokratische Geschichtsschreibung. Ausgewählte Abhandlungen, (ed. M. UNGER), Berlin, 1971, (Forschungen zur mittelalterlichen Geschichte,Band 18), p. 377-446. (In bijlage editie van een reeks brieven uitgewisseld tussen Pirenne en Sproemberg, waarin de eerste uiting geeft aan zijn nostalgie naar het Duitsland dat hij in zijn jaren als aankomend historicus heeft gekend: een maand voor zijn overlijden heet het: 'Les photographies de Berlin que vous avez eu la gracieuseté de m'envoyer m'ont fait le plus grand plaisir. J'ai tant appris dans son Université et j'y ai laissé tant de bons souvenirs ! Le reverrai-je avant de mourir ?'

35 Bulletin de l'Académie royale de Belgique, classe des lettres, 5-6, 1919, p. 14. 


\section{HENRI PIRENNE}

De mooie kritische editie van de briefwisseling van Huizinga die we sinds enkele jaren tot onze beschikking hebben laat evenwel toe hun gedachtewisselingen te reconstrueren, een dialoog die reeds voor de eerste wereldoorlog aanvangt wanneer de tien jaar jongere Huizinga naar Gent komt om er met eigen ogen het door Pirenne geïntroduceerde praktische onderwijs te komen observeren $^{36}$. In het voorjaar van 1933 had Huizinga als rector van de Leidse universiteit een internationaal studenten congres verwelkomd, evenwel niet zonder de leider van de Duitse delegatie, dr. Johann von Leers (1902-1965) auteur van een antisemitische brochure (Forderung der Stunde : Juden raus!, Berlin, 1928, 1933) namens de universitaire gemeenschap zijn afkeer te laten kennen. Het onderhoud eindigde met de gedwongen aftocht van de Duitse delegatie. Terug in Berlijn nam Von Leers revanche door van het Historische Zeitschrift gedaan te krijgen dat na de tekst van een lezing die Huizinga kort voordien in Berlijn gehouden had, de nota werd opgenomen dat indien de redactie eerder van het incident Huizinga-Von Leers had geweten, ze Huizinga's tekst nooit had afgedrukt ${ }^{37}$. Als represaille zegde het Tijdschrift voor geschiedenis haar ruilabonnement met het Historische Zeitschrift op. En onmiddellijk kruipt de oude Pirenne in zijn pen om aan Johan Huizinga het volgende te melden:

'Votre belle attitude à l'égard de la brutalité hitlérienne a été digne d'eux. L'Historische Zeitschrift vous a exclu honoris causa et nous avons tous applaudi ici à la riposte si méritée de la Tijdschrift voor geschiedenis. Jusqu'où les aberrations du racisme entraîneront-elles ces malheureux allemands? Qui donc a dit : 'Der Weg der Menschheit geht von Humanität, durch Nationalität, zur Bestialität'?' 38

Twee maanden voor zijn overlijden had Pirenne nog weinig van zijn in de jaren na 1918 zo fel klinkend engagement ingeboet.

Het is merkwaardig vast te stellen dat de huidige Duitse mediëvistiek nog steeds enigszins met gêne op de hele zaak Pirenne terugblikt. Nog in 1995

36 Zie mijn in druk zijnde studie over de relatie tussen beiden: M. BooNE, 'L'automne du Moyen Age': Johan Huizinga et Henri Pirenne ou 'plusieurs vérités pour la même chose', in: 'L'automne du Moyen Age. Textes, iconographie, philologie. Journées pour Alberto Varvaro (chaire Francqui au titre étranger 2003-2004), éd. P. Moreno, G. Palumbo,(Bibliothèque de la Faculté de Philosophie et Lettres de l'Université de Liège,...).

37 Het ging concreet om volgende tekst: J. HuizingA, Burgund, eine Krise des romanisch-germanischen Verhältnisses, in: Historische Zeitschrift, CXLVIII, 1933, p. 1-28 (heruitgegeven in Huizinga's Verzameld Werk, II, p. 238-265).

38 J. HuIZINGA, Briefwisseling II, ed. L. HANSSEN, W.E. KRUL, A. VAN DER LEM, Veen-Utrecht, 1990, p. $492\left(n^{\circ} 1064\right)$ waar ook het citaat geidentificeerd is als komend uit een gedicht van de 19de eeuwse Oostenrijkse dichter Franz Grillparzer. 


\section{MARC BOONE}

vond een der meest getalenteerde en gerenommeerde hedendaagse Duitse mediëvisten, Otto Gerhard Oexle het nodig zijn landgenoten uit te dagen met een essay 'Was deutsche Mediävisten an der französischen Mittelalterforschung interessieren muss' een titel met een bewuste knipoog naar Pirenne's 'ce qu'il faut désapprendre de l'Allemagne' 39 . Tot ver in de jaren 50 was het nog steeds bon ton om zich in Duitsland af te zetten tegen de verworvenheden van de Annales school die, bijvoorbeeld door Heimpel op de openingsrede van de Historikertag in Ulm in 1956, als een nieuwe versie van de Lamprechtiaanse kultuurgeschiedenis van omstreeks 1900 werd voorgesteld, iets wat toen nog kon tellen als veroordeling ${ }^{40}$. Deze negatieve houding is nu dan wel grotendeels weggewerkt (of de generatie die ze formuleerde is zo goed als uitgestorven) de relatie tussen een geschiedbeoefening die ofwel nomothetisch dan wel ideografisch georiënteerd is blijft moeilijk. In de onmiddellijke nadagen van Huizinga en Pirenne was de keuze, zoals de studies van dezelfde Oexle over het historisme en de Historikerstreit aan het einde van de $19^{\text {de }}$ en in de eerste helft van de $20^{\text {ste }}$ eeuw aangeven geen waardevrije, van de wereld onthechte activiteit. Het ging niet alleen over geschiedtheoretische opvattingen maar ook over een totaal opvatting over mens en samenleving, die met de opkomst van het nazisme op de achtergrond allesbehalve vrijblijvend was ${ }^{41}$. Misschien zit in het engagement voor een wetenschappelijke geschiedschrijving die zich bewust afkeert van nationalisme, irrationalisme, en vergelijkbare 'théories fumeuses' dat Pirenne en vele van zijn strijdvaardige tijdgenoten met hem beleden hebben of waarvoor ze, het voorbeeld van Marc Bloch voor ogen een grote prijs hebben betaald, een les voor een periode waarin een allesomvattende postmoderne twijfel om zich grijpt. Is het dit dan 'que nous pouvons encore apprendre de Henri Pirenne?'.

39 Nog steeds aktueel zie W. Paravicin, Zwischen Bewunderung und Verachtung. Französische und deutsche Mediävistiek seit dem letzten Kriege, in: P. MORAW, R. SCHIEFFER (ed.), Die Deutschsprachiche Mediävistiek im 20. Jahrhundert, (Vorträge und Forschungen LXII), Ostfildern, 2005, p. 181.

$40 \quad$ Ibidem, p. 178.

41 Zie O.G. OExıE, L'historisme en débat. De Nietzsche à Kantorowicz, Parijs, 2001 (vertaling van zijn Geschichtswissenschaft im Zeichen des Historismus, Göttingen, 1996), passim en O G. OEXLE, Das Mittelalter und das Unbehagen an der Moderne. Mittelalterbeschwörungen in der Weimarer Republik und danach, in: Spannungen und Widersprïche. Gedenkschrift für Frantisek Graus, ed. S. BURGHARTZ, H.-J. GLOMEN, G. Marchal, R.C. SchWINGeS, K. Simon-MuscheID, Sigmaringen, 1992, p. 125-153. 
HENRI PIRENNE

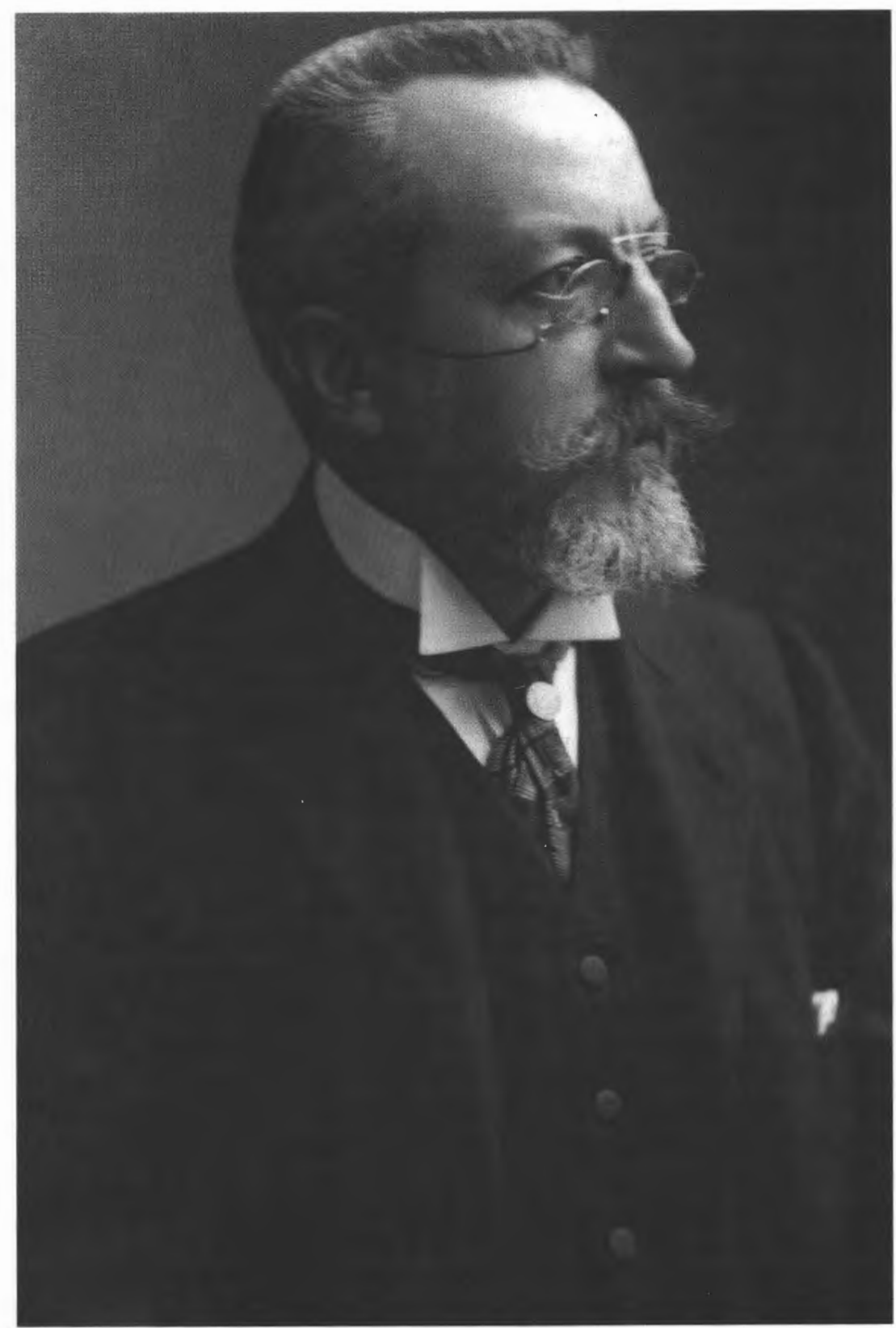

Henri Pirenne (Archief van de Universiteit Gent) 